\title{
The Motion of Intellect On the Neoplatonic Reading of Sophist 248e-249d
}

\author{
Eric D. Perl \\ Loyola Marymount University, Department of Philosophy \\ 1 LMU Drive, Suite 36oo, Los Angeles, CA 90045 \\ eperl@lmu.edu
}

\begin{abstract}
This paper defends Plotinus' reading of Sophist 248e-249d as an expression of the togetherness or unity-in-duality of intellect and intelligible being. Throughout the dialogues Plato consistently presents knowledge as a togetherness of knower and known, expressing this through the myth of recollection and through metaphors of grasping, eating, and sexual union. He indicates that an intelligible paradigm is in the thought that apprehends it, and regularly regards the forms not as extrinsic "objects" but as the contents of living intelligence. A meticulous reading of Sophist $248 \mathrm{e}-249 \mathrm{~d}$ shows that the "motion" attributed to intelligible being is not temporal change but the activity of intellectual apprehension. Aristotle's doctrines of knowledge as identity of intellect and the intelligible, and of divine intellect as thinking itself, are therefore in continuity with Plato, and Plotinus' doctrine of intellect and being is continuous with both Plato and Aristotle.
\end{abstract}

\section{Keywords}

Plato - Plotinus - Aristotle - Sophist - being - intellect - motion

Plato's forms are often characterized — not to say caricaturized — as inert, lifeless objects, enthroned in a "Platonic heaven" like so many lumps of intelligible stone. In the Sophist, however, in a passage which is usually altogether ignored

* Extensive portions of this article have appeared previously in Perl (2014).

(C) PERL, $2014 \mid$ DOI $10.1163 / 18725473-12341285$

This is an open-access article distributed under the terms of the Creative Commons AttributionNonCommercial 3.0. Unported (CC BY-NC 3.0) License, http://creativecommons.org/licenses/by-nc/3.0/ 
in such accounts of Plato's thought, Plato himself expressly ridicules this conception of intelligible reality. The "friends of the forms" (248a4), we are told, say that "by the body through sensation we commune with becoming, but through reasoning, by the soul, with real reality, which you say is always the same, while becoming is different at different times" (248a10-13). The Eleatic Stranger takes the supposed "changelessness" of real reality to mean that, according to the "friends," it neither does ( $\delta \rho \hat{\alpha} \nu, 248 \mathrm{c} 5 ; \pi 0 เ \varepsilon \hat{\imath} \nu, 248 c 8)$ nor undergoes $(\pi \dot{\alpha} \sigma \chi \varepsilon i v, 248 c 8)$ any activity. He then points out that if knowing and being known are things done and undergone $\left(248 \mathrm{~d}_{4}-\mathrm{e} 4\right)$, these would therefore, according to the "friends," be excluded from real reality, and exclaims, "But, by Zeus! Shall we easily be persuaded that, truly, motion and life and soul and thought are not present in that which completely is $[\tau \hat{\omega} \hat{\tau} \pi \alpha \nu \tau \varepsilon \lambda \hat{\omega} \varsigma$ oै $v \tau \iota]$, that it neither lives nor thinks, but, solemn and holy, not having intellect, it is standing unmoved?" (248e6-249a2). This, Theaetetus replies, would be a "dreadful

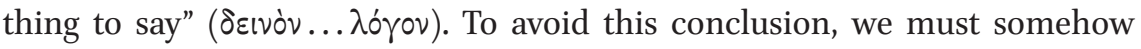
admit into "that which completely is" intellect, life, soul, and hence, in some sense, motion.

The interpretation of this passage marks one of the sharpest divisions between Neoplatonic and modern readings of Plato. ${ }^{1}$ According to the most common modern reading, Plato here recognizes, at last, that reality cannot consist solely of immovable forms, but must include also moving beings, whether this means changeable things in general ${ }^{2}$ or only souls. ${ }^{3}$ The forms are here

1 The Neoplatonic interpretation of this passage has had a few modern defenders, notably Pépin (1965); Vogel (1986); and, most recently and thoroughly, Gerson (2006). Neither Vogel nor Gerson, however, defends this interpretation by a meticulous reading of the passage such as is undertaken here (Part III). Moreover, they argue for this interpretation only on the basis of the Sophist itself, the Timaeus, and (in Gerson's case) the Laws, thus suggesting that they accept the diachronic reading of the dialogues that is rejected here; see below, n. 28 . The present study both supports Gerson's conclusion by providing different and more ample argumentation for it, and widens its scope by addressing the Sophist passage in relation to a broader range of issues, e.g., the "ocular metaphor" for knowledge and the developmental approach to the dialogues.

2 E.g., Brown (1998) 201-3.

3 E.g., Cornford (1935) 245; Leigh (2010) 77 and n. 28. Ross (1951) 108-11, seems to adopt both positions. He says first (111), "What [Plato] does in the Sophistes is to recognize, more explicitly than ever before, two elements in reality—universal Forms and individual souls." But he continues, "Finally, summing up the argument, [Plato] says that reality must include all things immovable and movable; the immovable Forms which alone the Friends of the Forms admit to be real, the movable bodies which alone the materialists admit to be real, and the souls which have 'movements of their own."' 
interpreted as "objects of knowledge," and as such extrinsic to the thought that knows them. This is of a piece with Plato's supposed commitment to an "ocular metaphor" for knowledge, that is, a conception of knowledge as a "gaze" of the soul at intelligible objects extrinsic to itself. On this interpretation, therefore, Plato here realizes that in order to allow for knowledge we must admit not only the forms but also intelligence, life, and motion into reality. This passage is thus taken as a prime example of the increasingly discredited notion of chronological development in Plato's thought: ${ }^{4}$ in the so-called "middle" dialogues, such as the Phaedo, Phaedrus, and Republic, only the immovable forms are regarded as "really real," while in the "late" Sophist Plato admits moving things into full reality. 5

Plotinus, however, who of course never dreams of reading Plato in developmental terms, interprets this passage very differently. He sees it as one of the clearest statements within Plato's dialogues of his own doctrine of the unity-in-duality of intellect and being, or the forms. Plotinus argues that since

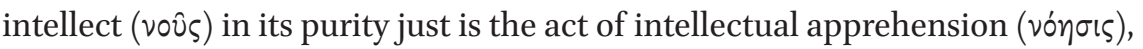
it has being as its very content and thus "is itself the things which it thinks" (v.9.5.7). If, on the other hand, being were extrinsic to intellect, then what intellect actually apprehends would be not being itself but only an impression or representation of it. Intellect, therefore, would not know reality itself, or, more precisely, would not be the very knowledge of reality: "If one grants that these things [i.e., the intelligibles] are most outside [of intellect], and that intellect, having them, beholds them thus [i.e., as outside itself], it is necessary that it not have what is true of them and be deceived in all things which it beholds. For they would be the true things; and it will behold them, not possessing them but receiving images of them in such knowledge. But if it does not possess what is true, but takes into itself images of the true, it will possess falsehoods and nothing true" (v.5.1.50-58). There would always be a difference between what intellect has, on the one hand, and reality itself, on the other, and hence its thinking, the thinking which it is, would not be true (cf. v.3.5.19-25). On this theory, then, intellect would not be the apprehension of reality itself, and so would not genuinely be intellect. "If then truth is not in intellect, such an intellect will not be truth, or truly intellect, nor will it be intellect at all" (v.5.1.65-67). In order to be knowledge, thinking must coincide with being. Conversely, if being were extrinsic to intellect, then being itself, as distinct from an image, impression, or representation of being, could not be that which is thought or

4 On reasons for rejecting the diachronic reading of Plato see, inter alia, Desjardins (2004) 89-9o n. 24; Griswold (2002); Howland (1991).

5 E.g., Cornford (1935) 242-43; Sayre (2005) 224-25. 
known. Thus if intellect and the intelligibles were separate from each other, not only would intellect not be intellect, because it would not be the apprehension of being, but also the intelligible would not be intelligible, because it could not be apprehended by intellect. In order to be what is known, being must coincide with thinking. "One must not, then, seek the intelligibles outside [of intellect], nor say that there are impressions of being in intellect, nor, depriving it of truth, produce ignorance and non-existence of the intelligibles and, further, abolish intellect itself" (v.5.2.1-4).

Plotinus concludes, therefore, that "since it is necessary to bring in knowledge and truth and to preserve the beings and knowledge of what each is," and that if we could not know beings themselves "we would have an image

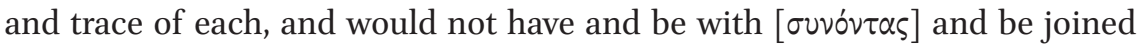
together with the things themselves," it follows that "all things must be given

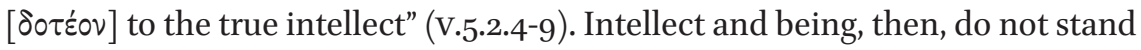
apart as "subject" and "object," two separate spheres or realms having only an

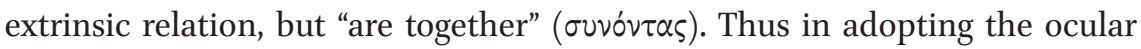
metaphor for knowledge Plotinus expressly eliminates any separation between "subject" and "object" that this might be taken to imply: "If, then, sight is of the external, there must not be sight, or only thus, as the same as that which is seen" (v.8.11.21-22). The forms, therefore, are not inert "objects" but are the contents of living intelligence and as such are one with it in the unity of act and content, apprehension and the apprehended. "But if intellection and the intel-

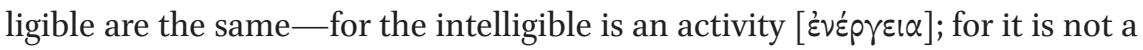
potentiality, and not unintelligible, nor apart from life, nor, again, do living and thinking come from without to another being, as if to a stone or something inanimate - then the intelligible is the primary reality" (v.3.5.31-35). It is in this sense that motion, life, and intelligence, but not temporal change, belong to "that which completely is."

According to most modern interpreters, this doctrine has no real basis in Plato, but is rather Plotinus' original (or perverse) development of Aristotle's doctrines that "contemplative knowledge and that which is known in this way are the same" (On the Soul Г.4, 429b30-430a5) and that the unmoved mover is "thought thinking itself" or "the thinking of thinking" (Metaphysics $\Lambda .7$, 1072b20; $\Lambda .9,1074$ b35). I propose to argue, on the contrary, that in this respect both Aristotle and Plotinus are in accord with Plato. The coinciding of intellect and the intelligibles is not only the best interpretation of the Sophist, on the basis of a meticulous reading of the text, but also Plato's consistent understanding of the relation between intelligible being and intellectual apprehension. Not only in the Sophist, but throughout the dialogues, Plato regards the forms not as lifeless objects extrinsic to, apart from, or over against thought 
or knowledge, but rather as the content of and thus together with the activity of intellectual apprehension. This activity in its purity is the demiurge or god, who is therefore one with divine, intelligible being. The human soul, in turn, is together with the forms just insofar as it partakes in this activity or, as Plato puts it, "has intellect." Plato never understands knowledge as a mere "gaze"

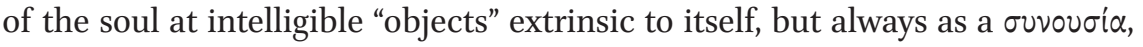
a togetherness with being which is represented not merely by the metaphor of seeing but by those of touching, grasping, eating, and sexual union. The Sophist's insistence that life, intellect, and in this sense motion must belong to "that which completely is" is therefore not a change in Plato's thought but accords with his understanding of the relation between intellect and the intelligible as we find it throughout the dialogues.

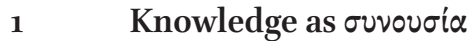

Plato's extensive use of the "ocular metaphor" for knowledge which is implicit

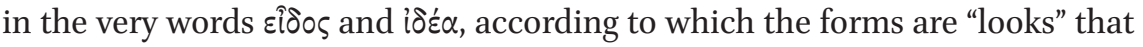
the soul "sees," is often taken to mean that Plato thinks of knowledge in terms of an extrinsic relationship between the knower as "subject" and the forms as "objects." But if we find such a subject-object dualism in Plato, this is only because we ourselves are thinking like moderns and presuppose that "seeing" must be interpreted in this way. In fact, what Plato means by "seeing" is much closer to what in phenomenological terms is called "intuition," 6 which may be analyzed into the intentionality of apprehension and the givenness of that which is apprehended. Understood in this way, "seeing" implies not extrinsic objectification and representation but, on the contrary, the immediate togetherness of seeing and seen. Insofar as I see anything, I am "out there" with that which is seen, and, conversely, that which is seen is "in" me as the content of my visual awareness. Seeing, or any mode of awareness, implies not a separation between subject and object but rather a joining, a being-together, of apprehension and reality. And it is in precisely these terms that Plato presents the relation between intellectual apprehension and intelligible being, or the forms. The forms, as intelligible "looks," are given to and are thus in intellect as its content, and indeed Plato occasionally refers to them not only as

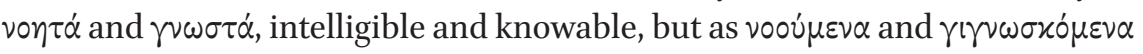
(e.g., Republic 58oc1, e2). The common translation of these terms as "objects

6 This term, we should note, translates German Anschauung and is derived from Latin intuere, both of which refer to "beholding." 
of thought" and "objects of knowledge" is misleading. The term 'object,' like its German equivalent Gegenstand, implies something that stands "over against" and is thus extrinsic to thinking or knowing. The Greek participles, on the other hand, mean rather "that which is thought" and "that which is known," or, still more briefly and precisely, "the thought," "the known," and thus imply rather the content of thinking and knowing. Conversely, the soul, insofar as it is intellectual, is together with the forms, possessing them as that-whichit-thinks or knows. Plato thus understands the relation of thought and being not as an extrinsic subject-object duality but as a $\sigma u v o v \sigma i \alpha$ or being-together, a conjugal union of the knowing and the known.

One of the chief ways in which Plato expresses this togetherness is through the myth of recollection, the central point of which is that the soul does not take in the forms from outside, but discovers them within itself. It is all too rarely recognized that Plato's account of our coming to know the forms as a recollection of what we knew in a previous, discarnate existence but forgot upon being born in the body is not a "theory" or a "doctrine" but a myth, even though it is clearly presented as such not only in the Phaedrus but in the Phaedo and the Meno as well. ${ }^{7}$ In the Meno, it is first introduced as a tale told by priests and poets (81a10-b6). Then, upon completing the argument for recollection through the discovery of mathematical knowledge in the untaught slave-boy, Socrates says, "Then if for us the truth of beings is always in the soul

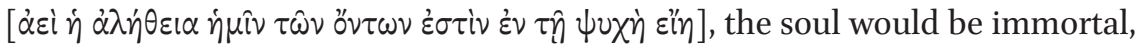
so that you must boldly try to seek and to recollect [ $\alpha \nu \alpha \mu \mu \nu \eta \eta \dot{\sigma} \sigma \varepsilon \sigma \sigma \theta \alpha l]$ what you

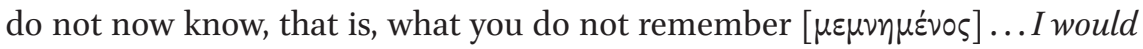
not altogether rely on this account in other respects; but if we hold it necessary to seek what one does not know we would be better and more courageous and less idle than if we hold that it is not possible to find it and need not seek: for this I would altogether contend in both word and deed" (86bi-c2). The key point on which Socrates insists, then, is not the tale itself, but that knowledge is possible for us, and hence we must seek it, because "the truth of beings is

7 For a thorough account of why recollection should be regarded as a myth see Dorter (1972) 215-17. Dorter summarizes (217): "There are thus a number of reasons for supposing the doctrine of recollection to be a genetic myth depicting the relationship between the embodied soul and the forms: the indications in the direction of the purification acount that occur toward the end of the discussion of recollection in the Phaedo; the mythological context in which the doctrine of recollection is always presented; the simplemindedness of the details of recollection, and their incompatibility with those of purification; the depiction of the 'prenatal' soul in the Phaedrus, as tripartite, which implies that it is really incarnate; the way in which the details of the Phaedrus myth echo those of the Phaedo's account of incarnate learning; and the similarity between the Phaedrus myth and the genetic myth of the Timaeus." 
always in the soul." The real conclusion of the argument is not that the soul literally pre-exists but that "the truth of beings" is found not outside of but within the soul. This, indeed, is all that is justified by the conversation with the slave-boy: it shows, at most, that since he did not receive his knowledge of mathematical truth from outside, he discovered it within himself. It does not and cannot prove that he acquired this knowledge at some time in the past, before he was born. The word "always" points in the same direction: if the truth is always in the soul, then it was not received at some time in a previous existence prior to which it was not there, but rather is intrinsic to the soul. The story that this knowledge was acquired in a previous existence must therefore be taken as a mythic expression of the soul's intrinsic possession of truth, that is, of intelligible reality.

In the Phaedrus, Socrates likens the soul to a pair of winged horses and their charioteer, and describes its "journey," following the gods, to "the place above the sky" $(247 \mathrm{c} 3)$ where it "beholds" $\left(247 \mathrm{~d}_{3}, \mathrm{~d}_{5}-6\right)$ the forms. The strongly visual imagery and the references to a "place" may incline us to read this as a pre-natal voyage to "another world." But Socrates has already warned us that he is telling not "what the soul actually is" but rather "what it is like" (246a5) and later expressly refers to this story as a "mythic hymn" (265c1). The "place above the sky" is not in fact a place, since what is "there" has no shape or color, is not bodily at all. And if the spatial dimension of the soul's "journey" is obviously metaphorical, then so too is the temporal dimension. To imagine, that is, to picture the soul pre-existing in time, is necessarily to picture it being in some place at that time. The flight, therefore, must rather be understood as a mythic representation of the psychic, cognitive attainment of an intellectual apprehension of the forms "themselves by themselves." The forms are metaphorically represented in spatial terms as "outside" the entire cosmos in that they are not themselves sensible things, not additional members of the sensible world. Likewise, they are represented as being known prior to our birth in that they do not come to us from outside, by way of sense-perception. That the soul's flight is a metaphor for intellectual apprehension becomes still more evi-

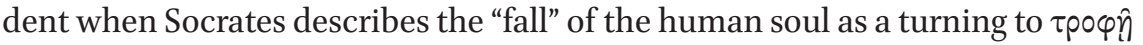
$\delta \circ \xi \alpha \sigma \tau \hat{\eta}$, "opinion-food" (248b5). The fall is thus a descent to a lesser mode of apprehension, to opinion rather than knowledge. The entire myth of the soul's flight, its fall, and its recollection of what it saw must therefore be understood not literally, as a chronological narrative of the soul's life-history, but rather as a

8 Translating this phrase as "the place beyond heaven" obscures the spatial imagery of a geocentric cosmos in which one may ascend from earth, through the celestial spheres, to the place that is literally above the sky and thus outside the entire cosmos. 
mythic representation of different levels of cognitive apprehension. The divine level is the intellectual apprehension of forms; the human soul, as imperfectly intellectual, is not at this level but may be on its way to it, working from the multiplicity of sensible appearances toward intelligible unities. Thus, later in the Phaedrus, Socrates describes the "method of collection and division," or

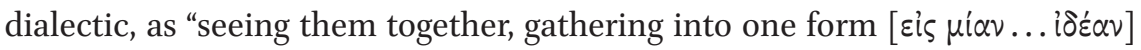
the things that are scattered everywhere" and "being able to cut according to forms $\left[\kappa \alpha \tau^{\prime} \varepsilon^{\prime} \delta \emptyset\right]$ at the natural joints" $\left(265 \mathrm{~d}_{3}-4,265 \mathrm{e}-2\right)$. He then alludes back to the myth: "I myself am a lover of these divisions and collections, so that I may be able to speak and think; and if I judge that anyone else is able to see a one which is by nature over many, I follow 'behind in his track as if he were a god'" (266b3-7). To "follow a god" to "the place above the sky" $(247 \mathrm{c} 3)$ is thus to recognize, intellectually, the intelligible forms that articulate sensible things, enabling them to be anything and enabling us "to speak and think," to understand the world, at all.

In the Phaedo, the soul's "going to" the forms at death, and hence also its "coming from" the forms at birth, is a less vivid and graphic version of the same myth. Here Plato expressly links the spatial and temporal aspects of the recollectionstory through the words of Cebes, who throughout the dialogue is shown to have an incorrigibly pictorial and bodily notion of the soul (e.g., 70a1-6; 87b4-88b8): "This [i.e., recollection] is impossible, unless our soul exists somewhere [ $\pi \circ 0]$ before $[\pi$ piv] it comes to be in this human form" (72e7-73a2). As the spatial location of the soul and the forms in "the place above the sky" (Phaedrus) or in "Hades" (Phaedo) is clearly mythic in that it represents both the soul and the forms as bodies, so is the temporal location of the soul and the forms that is implied by "pre-existence." Taken literally in a temporal sense, the story of preexistence and recollection is altogether grotesque: it would mean that at a certain date, say, in 429 B.C.E., a year before Plato's birth, Plato's soul was “above the sky," "looking at" the forms. This not only assimilates the soul to a body, but assimilates intellectual apprehension to sense-perception, a taking in of content from outside, whereas the whole point of the recollection-story is that our knowledge of the forms is not taken in from outside but is "always in the soul."

What the argument for recollection in the Phaedo actually demonstrates is that our knowledge of the forms is non-empirical in just this sense. Socrates begins by making the distinction between equal things and "the equal itself," or the form equality: "We say, I suppose, that there is something equal, I mean not a stick [equal] to a stick or a stone to a stone or anything else of that sort, but besides all these things something else, the equal itself" (74a9-11; cf. 74c4-5). He then asks, "Whence do receive knowledge of it?" (74b4). We do in fact have such knowledge: if we did not know such a criterion, we could not identify any- 
thing we experience as unequal. "When someone, seeing something, thinks that what I now see wants to be such as some other of beings but is deficient and is not able to be such as that, but is inferior, it is necessary, I suppose, that

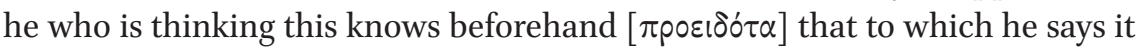
is like, but deficiently" (74d9-e4). For that matter, without the knowledge of equality neither could we identify anything we experience as equal. In making such judgments, we are bringing to bear an idea of equality and saying that the things perceived either do or do not display this "look." On the one hand, the experience of equal things is what, as we say, "calls to mind," or arouses in us, the knowledge of equality: "From these equal things, although they are different from that equal, you have nonetheless come to think and have received the knowledge of it" (74c7-9). On the other hand, sense-experience does not provide or account for this knowledge. Since equality itself, like any form, is not a sensible thing but an intelligible idea, it cannot come to us by way of the senses. Nor can we have arrived at it by "abstraction" from what we perceive, for this would require that we first identify such things as equal, which in turn requires that we already have the idea of equality. Since we apply this paradigmatic idea in judging what we perceive, our knowledge of it is in some sense prior to sense-experience: "Then it must be that before we began to see and hear and otherwise sense, we received knowledge of what the equal itself is, if we were going to refer thither the equal things from the senses..." (75b4-7). Consequently, Plato uses the metaphor of recollection to describe this discovery within ourselves of something that does not come into us from outside by way of the senses. The metaphor is both apt and powerful, because of the oddity of the everyday experience of forgetting and recalling. If I have forgotten something, or simply happen not to be thinking of it at the moment, in a sense I do not know it: it is not present to my awareness, I am not apprehending it. But if, upon being reminded, I recall it, I do not re-acquire it as a new piece of knowledge. Rather, I discover it within myself as something that, in some sense, I knew all along. What we have forgotten but can recall we both know, in that it is within us, and do not know, in that we are not currently apprehending it. Recollection thus serves as a superb metaphor for our coming to know the forms, which in one sense we do not initially know but which, "by using the senses" (75e3), we recognize as always already at work within our cognition.

The soul's "pre-existence," then, must be taken as a metaphorical expression of its intrinsic possession of intelligible reality within itself. Just as, in the Meno, the real conclusion of the argument for recollection is that "the truth of beings is always in the soul," so too, in the Phaedo, the conclusion is that intelligible reality "is ours" (76e1-2). Since our knowledge of the forms does not come into us by way of the senses, it is non-empirical and in that sense 
a priori. We rarely notice that this common philosophical expression, which has become sedimented as a technical term for that aspect of our cognition which is not empirical, is itself a temporal metaphor. What is a priori is "prior" to sense-experience only in the sense that it does not come to us by way of such experience. The meaning of Plato's myth is that our knowledge of the forms is a priori in just this sense. Indeed, whenever we speak of an a priori dimension of knowledge not only are we using a metaphor, but, whether we realize it or not, we are invoking Plato's myth of pre-existence and prior knowledge. Since we do not mean it literally ourselves, why should we think that Plato does so, when in fact he openly tells us that it is a myth?

The myth of pre-existence and recollection is thus an expression of the human condition as "in between," a condition of not being gods, that is, not being sheer intellectual apprehension itself, and yet capable of attaining such apprehension to some degree. This is indicated by the distinction in the Meno between "remembering" ( $\mu \varepsilon \mu \nu \eta \mu \varepsilon v o \varsigma)$, that is, immediately apprehending, and "recollecting" ( $\dot{\alpha} \nu \alpha \mu \mu \nu \eta \eta \dot{\sigma} \kappa \varepsilon \sigma \theta \alpha \mathrm{l})$, that is, working toward apprehension (86b3-4). Such attainment is possible because of the latent presence within us of divine, intelligible being. What the argument shows is that the forms are in us, for without them we could not think at all or make any identifying judgments about what we perceive. Intelligible being must belong intrinsically to the soul, for otherwise we could never come to know it and thus would not be capable of intellection. Since intellect, that is, intellectual apprehension, just is the possession of the forms, it follows that intelligible reality lies not outside of but within such apprehension, and hence within us insofar as we "have intellect." The real point of the story of recollection, then, is not literal, temporal pre-existence, but rather interiority: we do not take in divine, intelligible being from outside, but find it within ourselves. Intelligible being, therefore, is not apart from but is rather contained within living intelligence, the activity of intellectual apprehension.

Thus when Plato presents knowledge in terms of the "ocular metaphor," he expressly understands this not as an extrinsic duality but rather as a joining together of the seeing and the seen. In laying out the analogy of the good to the sun, he observes first that light is the "yoke" that "yokes together" vision and the visible. "By no small idea, then, the sense of sight and the power of

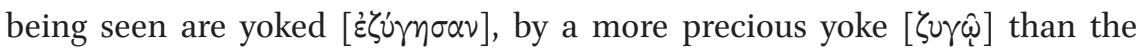
yokings-together [ $\sigma 0 \zeta \varepsilon \dot{\xi} \xi \varepsilon \omega \nu]$ of other things, if light is not worthless" (Republic 507e6-508a2). ${ }^{9}$ The term $\sigma \dot{\zeta} \zeta \varepsilon v \xi ı \varsigma$ carries a wide range of meanings, from the

9 Heidegger (1996) 230, takes this passage to indicate that truth is brought "under the yoke" of the $i \delta \varepsilon \dot{\varepsilon} \alpha$. But Plato in fact uses the metaphor of the yoke to express not sub-jugation but 
most literal, the uniting of two oxen under a common yoke, to marriage and sexual union. In the same way, our Latinate word 'conjugal' refers to marriage under the image of "yoking together." Having described vision in these terms, Plato continues, "This, then, say I called the offspring of the good, which the good begot as an analogue to itself; what that [i.e., the good] is in the intelligible place, with regard to intellect and the things that are thought $[\tau \varepsilon$ voôv xai $\tau \dot{\alpha} \nu \circ o v ́ \mu \varepsilon v \alpha$ ], this [i.e., the sun] is in the visible, with regard to sight and the things that are seen" (508b12-c2). Just as the sun, in providing light, enables the togetherness of seeing and the seen without which there is neither any seeing nor anything seen, so the good enables the togetherness of intellect and the intelligible, without which there is neither any intellectual apprehension nor anything apprehended. "Say, then, that this, which provides truth to the things known and gives power to that which knows, is the idea of the good" (508e1-3). This is precisely why, as Plato goes on to say, "not only is their being known present to the things that are known by the good, but also that their being and

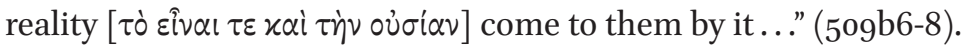

Plato frequently expresses this togetherness by describing knowledge as a ouvovoía, a "being-with" the forms. In the Phaedo, he uses this term to refer both to the unphilosophical soul's association with the body and to the philosophical soul's communion with intelligible, divine reality (e.g., 81c5, 83e3; see also 68a6-7). Like $\sigma \dot{\zeta} \zeta \varepsilon v \xi ı \zeta$, this word, signifying most literally "being-with" or "being-together," expresses a wide range of meanings, from social to educational to sexual intercourse, and was used by the Greeks to refer, among other

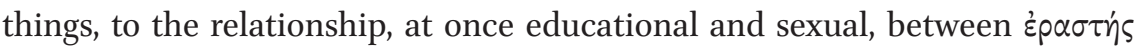
and $\dot{e} \rho \dot{\omega} \mu \varepsilon v 0 \varsigma$. In Plato's usage this term often has strongly sexual connotations. In the Seventh Letter (341c6) it refers to a philosophically transformed ver-

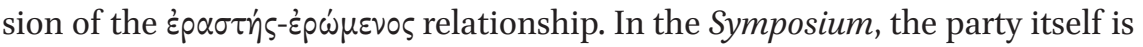

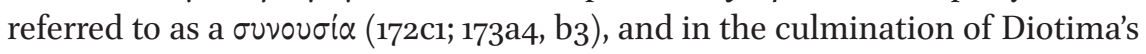
speech she first uses this term in its erotic sense, with regard to the boys whom

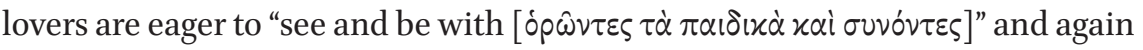

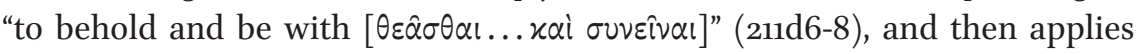
it to the philosopher's relationship with the form of the beautiful itself: "Do you think, then, that it would be a poor life for a man, looking at and beholding that in the way that is necessary, and being with [ouvóvtos] it? Or do you not think... that only there will it come about for him, seeing the beautiful by that to which it is visible, to beget not images of virtue, in that he is not laying hold of an image, but true [virtue], in that he is laying hold of what is true?"

con-jugation, the joining together of seeing and the seen or knowing and the known. See Peperzak (1997) 101. 
(211e4-212a5). The intellectual soul's relation to intelligible being, then, is no mere extrinsic "looking at," but is rather an intimate communion, a possession, a "mingling" or "joining" represented by the image of sexual union.

Indeed, Plato is by no means exclusively wedded to the "ocular metaphor" for knowledge. He frequently presents knowledge not only under the metaphor of vision but also under those of touching, holding, sexual union, and eating. ${ }^{10}$ Thus in the Symposium the philosopher can "beget" ( $\left.\tau^{\prime} i x \varepsilon \varepsilon v\right)$ true virtue because he "lays hold of" ( $\dot{\varepsilon} \varphi \alpha \pi \tau 0 \mu \dot{\varepsilon} v \omega)$ the beautiful itself. Likewise in the Phaedo, we are told that the philosopher's soul "touches" or "lays hold of"

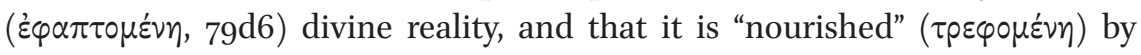
"the true and divine" (84a8-b1). In the Phaedrus, the soul not only "sees" but

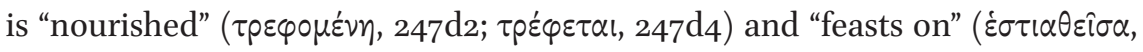
$247 \mathrm{e} 3)$ true being. In Republic IX Plato gives an extended description of the soul's being nourished and filled ( $\pi \lambda \eta^{\prime} \rho \omega \sigma \iota \varsigma, 585 \mathrm{bg} ; \pi \lambda \eta \rho \circ \dot{\mu} \mu \varepsilon v 0 v, \pi \lambda \eta p \circ \hat{\sigma} \sigma \theta \alpha \mathrm{l}$, $585 \mathrm{~d} 8,11,12)$ by intelligible reality $(585 \mathrm{bg}-586 \mathrm{~b} 4)$. Such expressions, implying that intelligible reality is the food and thus the very content of the intellectual soul, indicate a far more intimate union than a mere extrinsic gaze. In Republic VI Plato draws together the images of holding, eating, and sexual union to express the nature of knowledge: "It is natural that the true lover of learning strives toward being [ $\tau \dot{0} \partial \mathrm{v}]$, and does not remain with each of the many

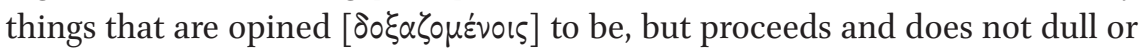

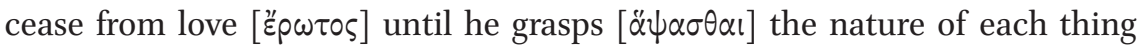
which is by that in the soul to which it is proper to lay hold [ $\dot{\varepsilon} \varphi \dot{\alpha} \pi \tau \varepsilon \sigma \theta \alpha l]$ of

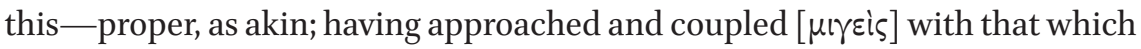

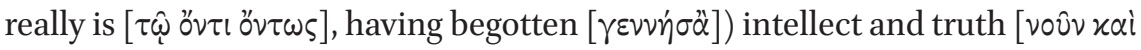

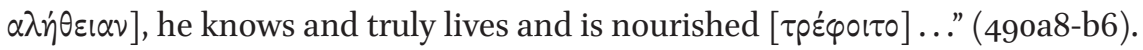
Intellect and truth are engendered, or come to be, in the soul, just insofar as it "couples" with real being, because intellect and truth just are the possession

10 Rorty (1979) 38-39, remarks, "There was ... no particular reason why this ocular metaphor seized the imagination of the founders of Western thought. But it did... The notion of 'contemplation,' of knowledge of universal concepts or truth as $\theta \varepsilon \omega$ pi $\alpha$, makes the Eye of the Mind the inescapable model for the better sort of knowledge. But it is fruitless to ask whether the Greek language, or Greek economic conditions, or the idle fancy of some nameless pre-Socratic, is responsible for viewing this sort of knowledge, as looking at something (rather than, say, rubbing up against it, or crushing it underfoot, or having sexual intercourse with it)." Rorty later, following Heidegger, associates the "ocular metaphor" specifically with Plato $(157,159,162-63)$. In view of Plato's regular and repeated accounts of intellectual knowledge in terms of, precisely, touching, holding, eating, and sexual intercourse, this is either disingenuous or indicative of a profound ignorance of, or disregard for, the text of Plato. 
and the givenness of being. The images of eating and sexual union, in particular, imply not merely no distance, but less-than-zero distance, between intellect and the intelligible. These metaphors thus represent a coinciding in which the two are joined in such a way that they occupy, so to speak, the same space

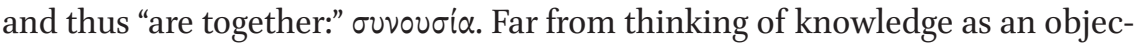
tifying "gaze" of the soul upon intelligible "objects" extrinsic to itself, Plato understands intellectual apprehension as a "being with" the forms, a possessing of intelligible being as its content, and, correspondingly, intelligible being as contained within intellectual apprehension. "The truth of beings is always in the soul" (Meno 86b1-2) and intelligible reality "is ours" (Phaedo 76e1).

\section{$2 \quad$ Demiurge and Paradigm}

The human soul, as we have seen, is not pure intellect but can be said to "have intellect" just insofar as it apprehends, possesses, or "is with" intelligible being. In the Timaeus, which is closely linked to the Sophist by the latter's reference

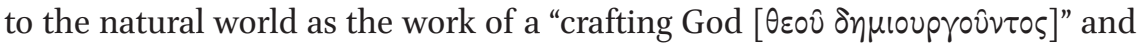

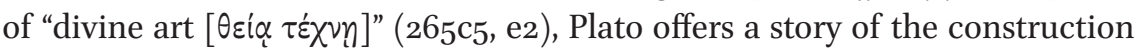
of the sensible cosmos by a god who just is intellect itself, and who is characterized as the $\delta \eta \mu$ iouprós, the craftsman, of the cosmos. What distinguishes craftsmanship from other modes of production, such as mechanical causation or biological procreation, is that a craftsman works intelligently, arranging his material according to a pattern, a plan or design, a paradigm, that is grasped by thought. So, for instance, in the Cratylus, Plato remarks that a carpenter makes

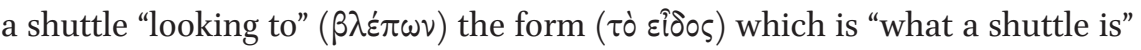
(389a6-b6). Likewise, in the Republic, Plato depicts the philosopher-king as an artist or craftsman ( $\delta \eta \mu$ oupyòv, 50od6) and says that such people, in "paint-

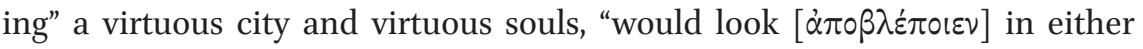
direction, toward the just and beautiful and moderate and all such things by nature [i.e., the forms justice, beauty, etc.], and toward what they are making

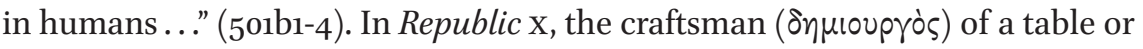

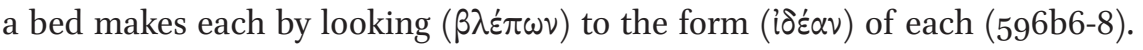
For Plato, then, artistic production or craftsmanship, demiurgy, is always a matter of "looking to" an intelligible paradigm and arranging the product so that it becomes an image of it. To say that the world as a whole is a work of divine craftsmanship is thus to say that, just as a work of human art reflects the paradigm that the artist beholds in his mind, so the cosmos expresses, or is an image of, the intelligible paradigm that the divine intellect apprehends:

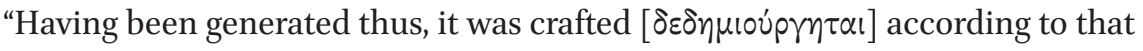


which is apprehended [ $\pi \varepsilon p l \lambda \eta \pi \tau \dot{0} \nu]$ by reason and thought and is always the same. These things being the case, again, there is every necessity that this cosmos is an image of something" (Timaeus 29a6-b2).

This is often taken to imply, once again, an extrinsic duality in which the forms are inert objects outside of and over against the divine intellect that "sees" them. But as we have seen, intellectual apprehension is the possession of and thus "is together" with intelligible reality. Unlike a human soul, which is not purely intellectual but may be said to "have intellect" and thus to share in divinity to a greater or lesser extent just insofar as it apprehends intelligible reality, the demiurge of the cosmos just is intellect, which is to say that he is intellectual apprehension or intelligence itself. As such, therefore, he coincides with the forms. Indeed, the term $\pi \varepsilon p \downarrow \lambda \eta \pi \tau \dot{0} v$ at $29 a 7$, here translated as "apprehended," means more literally "embraced" or "surrounded," and thus implies the containment of the paradigm by the divine intellect. A human craftsman, e.g., an architect, does not discover a blueprint extrinsic to himself and construct a house according to it. Rather, the pattern, the paradigm of the house, is in his mind as his idea, the content of his thought. If the architect is not altogether one with his idea, this is because a human architect is not nothing but the thinking of this paradigm. The demiurge of the cosmos, on the other hand, is nothing but thinking, nothing but intellectual apprehension itself, and thus is one with that which he thinks, that is, intelligible reality, the paradigm of the cosmos. ${ }^{11}$

Plato consistently presents the relation between craftsman and paradigm in just this way. In the Republic, explaining why only the philosopher is suited to rule the city, he points out that the "lovers of sight and sounds," "having no

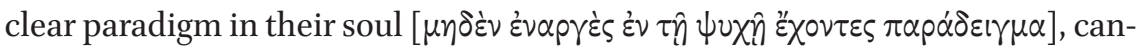
not, as painters do, looking to [ $\dot{\alpha} \pi \circ \beta \lambda \varepsilon \dot{\varepsilon} \pi 0 v \tau \varepsilon \varsigma]$ what is most true, always referring thither and beholding it as precisely as possible, thus establish here laws concerning beautiful and just and good things..." (484c7-d2). This implies that the philosopher, on the other hand, insofar as he knows the forms or "has intellect," does have such a "clear," that is, intelligible, paradigm in his soul. Thus Plato subsequently remarks that that philosopher "seeing and beholding things that are ordered and always the same, neither wronging nor being wronged by each other, being all in order according to reason, imitates these things and

11 This must not be mistaken for the quite different theory that the forms are "thoughts of god" in the sense that the demiurge is prior to and produces or "makes up" the forms. Rather, the forms, taken all together as one whole, are the content of the act-of-thinking which is the demiurge. Neither the seeing nor the seen, the apprehension nor the apprehended, can be prior to the other. Cf. Vogel (1986) 206. 
is likened to them as far as possible. Or do you suppose there is any way in which someone can consort [ $\dot{\delta} \mu 1 \lambda \varepsilon \hat{\imath}]$ with what he admires without becoming like it?... Then the philosopher, consorting $[\dot{\delta} \mu i \lambda \hat{\omega} v]$ with what is divine and orderly, becomes as orderly and divine as is possible for a man" (500c2-d1). The term that Plato twice uses here to describe the relation between the philosopher and the divine reality that he "beholds" is o $\mu \iota \lambda \varepsilon i v$, which, much like ouveival, signifies anything from social to marital to sexual togetherness, and indeed is used conjointly and synonymously with ouveival at Phaedo 81c5. It is at this point in the Republic that he depicts the philosopher as a "craftsman" who "looks to" to the forms and "paints" the virtuous city and souls "using the divine paradigm" (5ood6-e4). Significantly, these two passages, describing the philosopher as a craftsman with the divine paradigm in his soul, occur shortly before and shortly after the graphic account of the philosopher's soul coupling with and being nourished by real being (490a8-b7). In characterizing the philosopher as a craftsman, then, Plato indicates that his soul is in communion $(\delta \mu \nu i \alpha \alpha)$ with the intelligible paradigm to which it looks, and that this paradigm, as that which he "sees," that is, apprehends intellectually, is not separate from but is in his soul.

So, in the Timaeus, we are told that the demiurge of the cosmos "looked to" ( $\varepsilon \beta \lambda \varepsilon \pi \varepsilon v, 29 a 3)$ the eternal, intelligible paradigm in making the world. As we have seen, this "ocular metaphor" for intellectual apprehension implies not an extrinsic subject-object relationship but rather the "yoking" or "togetherness" of knowing and the known: the seeing is with the seen and the seen is in the seeing. Thus, as Plato here says, the paradigm is apprehended $(\pi \varepsilon p \iota \lambda \eta \pi \tau \dot{0} v$, 29a7), that is, more literally, "embraced" or "surrounded," by thought. The demiurge and the forms, then, are united in the ovvov $\sigma^{\prime} \alpha$ of intellectual apprehension and intelligible content. The forms, taken all together as the totality of all possible thought-contents, constitute thought itself, that is, the demiurge. The world, we may say, reflects intelligence, which is both the act-of-thinking, i.e. god or the demiurge, and that-which-is-thought, i.e. the forms or the paradigm. In this way we can understand Plato's references to the paradigm of the cosmos as "the intelligible living thing" (39e1) and as the "living thing... of which the other living things ... are parts. For," he continues, "that [i.e., that living thing] possesses all the intelligible living things, embracing them in itself [ $\dot{\varepsilon} \nu \dot{\varepsilon} \alpha \cup \tau \hat{\omega}$ $\left.\pi \varepsilon p 1 \lambda \alpha \beta \delta_{\nu}\right] "$ " (3oc3-8). We should note Plato's use of the same term to mean "contained" that he employed just before, at 29a7, to refer to the paradigm as "apprehended" by thought. If the intelligibles were inert objects, extrinsic to the living intelligence that "sees" them, how could they be living? But if we recognize that the seen, or known, is not outside of the seeing or knowing, these references make perfect sense: the forms are living as the contents of 
living intelligence, of thought itself. Thus Plato characterizes the paradigm in a variety of ways. First he calls it "that which is changeless and is apprehended [or embraced/surrounded] by reason and thought" (29a6-b1). A few lines later he says that the demiurge "wanted all things to become as like himself $[\pi \alpha \rho \alpha \pi \lambda \dot{\eta} \sigma \alpha \alpha \dot{\varepsilon} \alpha \nu \tau \hat{\omega}]$ as possible" (29e3), suggesting that the paradigm of the cosmos is the demiurge himself. Next he calls the paradigm the "living thing" of which all other intelligible living things are parts (3ос3-6). Taken together, these passages suggest that the forms, the demiurge, and the intelligible living thing are different ways of referring to the same paradigmatic reality. ${ }^{12}$ In that the sensible cosmos is an image of intelligible being, or the forms, it is a likeness of the demiurge himself, because these forms are the content of intellectual apprehension. As such it is an image of "the intelligible living thing," for the paradigm thus unites, in indissoluble togetherness, the act-of-thinking and that-which-is-thought. Just as an image of the forms, the world is an image of living intelligence itself.

\section{3}

\section{The Motion of Intellect}

In the Sophist, then, when Plato ridicules the conception of the forms as lifeless objects divorced from intellectual apprehension, he is repudiating a notion of intelligible being that was never his own. In the developmental reading, this passage is taken to mean that, contrary to the doctrine of the "middle dialogues," Plato is now including not only changeless, lifeless, intelligible forms but also living, changing things in the realm of being. On this interpretation, $\tau \hat{\omega} \pi \alpha \nu \tau \varepsilon \lambda \hat{\omega} \varsigma$ ö $v \tau \iota$ must be understood to mean "being as a whole," and motion is admitted into reality in the sense that "reality or the sum of things" includes living and moving things in addition to immovable forms. To support this reading, the text of $249 b 5-6$ is "emended" by the outright insertion of the word $\pi \dot{\alpha} v \tau \omega \nu$ so that it reads, "It turns out that if all beings are immovable then there

12 On reasons for not regarding the demiurge as an "efficient cause," separate from the paradigm and needed to account for the production of the cosmos, see Perl (1998) 83-85, esp. 85 . When Timaeus introduces into his account of the cosmos a "third kind," distinct from both the intelligible paradigm and the sensible image, this "third kind" is not the demiurge but the receptacle (48e2-49a6). He then (5oc7-d4) likens the receptacle to a mother, the paradigm to a father, and the image to their offspring, again with no reference to the demiurge. Since earlier $(28 \mathrm{c} 2)$ he refers to the demiurge as the "father" of the cosmos, this too may suggest that demiurge and paradigm are two ways of regarding the same principle. This point is of little value in itself, but, taken in conjunction with other indications, could arguably provide further support for the unity of demiurge and paradigm. 
is no intellect about anything anywhere,"13 implying that, on the contrary, some beings must be moved. According to this interpretation, the argument continues with the observation that if, on the other hand, all beings are moved, then likewise there can be no intellect (249b8-c5), for intellectual knowledge requires immovable realities as its objects. Some beings, then, must be unmoved. The conclusion, therefore, is that "being and the all" $\left(249 \mathrm{~d}_{4}\right)$ must include both immovable forms and moving things. ${ }^{14}$

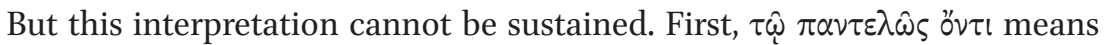
not "being as a whole" but rather "that which completely is:" $\pi \alpha \nu \tau \varepsilon \lambda \hat{\omega} \varsigma$ is an adverb expressing degree or intensity of being, not an adjective expressing inclusivity. ${ }^{15}$ Indeed, this is precisely the same phrase that Plato uses at Republic 477 a3 to refer to the forms, or intelligible reality, identifying it as that which is completely knowable. So too, here in the Sophist, it refers to the intelligible as the wholly real. If motion were allowed into reality only in the sense that not forms alone but also moving things are beings, then the forms themselves would remain inert and lifeless, "not having intellect."16 But it is precisely this view of intelligible reality, of the forms, that Plato is here mocking and rejecting, and which is contradicted in the Timaeus as well, where the paradigm of the cosmos is identified as "the intelligible living thing." The whole point of the Stranger's argument is that intelligible being itself must in some sense involve life, thought, and motion. The wholly unwarranted insertion of $\pi \alpha \dot{v} \tau \omega \nu$ at $249 b_{5}$ is nothing but a flagrant case of altering the text to make it say what a certain interpretation requires, an egregious violation of basic philological principles. ${ }^{17}$ What the Stranger actually says is, "It turns out that if beings

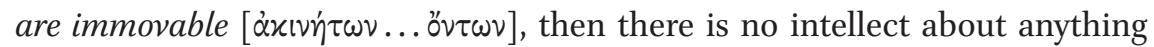

13 This so-called emendation is endorsed by Cornford (1935) 241 n. 1; Ross (1951) 109 n. 1; Brown (1998) 202 n. 43; Bluck (1975) 99; White (1997) 271.

14 For a classic exposition of this reading of the passage see Cornford (1935) 241-47.

15 Cf. Vogel (1986) 196-97.

16 Cf. Vogel (1986) 196-97: "For, after all, the Stranger from Elea did not say that something had to be added to that solemn and holy world of 'that which perfectly IS' - a moving kind of being to that which by its very nature was unmoving - , but his problem was: how

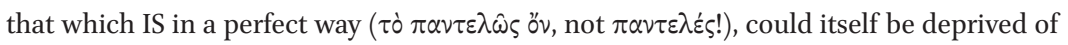
life and thinking. This problem could not be solved by adding to it a different kind of being which does possess life and thinking... [T] hat which is vontóv properly speaking would remain as 'solemn and holy' as ever: no life and motion, no soul and thinking would be proper to it" (italics in original).

17 Tristram Shandy, book 3, ch. 37: "I've done it—said my father, snapping his fingers—See, my dear brother Toby, how I have mended the sense.-But you have marred a word, replied my uncle Toby." 
anywhere" $(249 \mathrm{~b} 5-6) .^{18}$ The point is not that some beings must be moved, but that beings in general, intelligible reality as a whole, must be moved, if there is to be intellect. Thus in the next speech, $\pi \alpha^{\prime} \nu \tau$ ' does not modify $\partial v \tau \alpha$, thereby suggesting that it ought to be included in the previous speech as well, but is

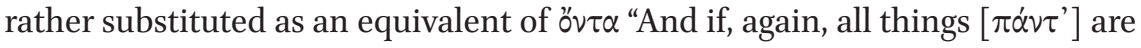
borne about and moved, on this account too we will take away the same thing [i.e., intellect] from beings" (249b8-10). The Stranger points out that in order to allow for intellectual knowledge, beings must, on the one hand, in some sense be moved, while all things - that is, the very same things, beings - must, on the other hand, in some sense also be immovable.

The equivalence of $\partial^{\prime} v \tau \alpha$ and $\pi \alpha \dot{v} \tau \alpha$, referring to all beings taken together, is indicated by the chiastic use of the terms $\tau \dot{\partial} \pi \hat{\alpha} \nu$ and $\tau \dot{o} \partial{ }^{\prime} v$ in the conclusion of the argument: "To the philosopher... it is necessary, for these reasons, neither to accept, from those who assert either one or many forms, that the all [ $\tau \dot{0} \pi \hat{\alpha} \nu]$ is static, nor, again, to listen at all to those who in every way [ $\pi \alpha \nu \tau \alpha \chi \hat{\eta}]$ move being [ $\left.\tau \dot{0} \partial^{\prime} v\right]$, but rather to say, as in the children's prayer, that being and the

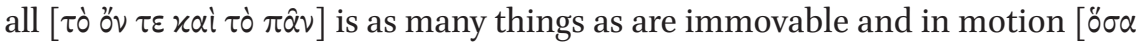

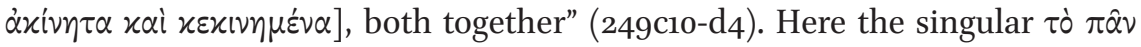

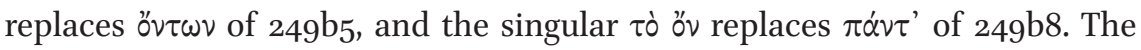
equivalence of these terms is then confirmed by their repetition in the explicit hendiadys $\tau \dot{o}$ óv $\tau \varepsilon$ xaì $\tau \dot{\partial} \pi \hat{\alpha} \nu$, "being, that is, the all." Thus the question to which the answer is "Both" is not, "Does being include immovable things or moving things?" but rather, "Is being as a singular totality immovable or moving?" Only this reading makes sense of the comparison to the "children's prayer," which implies a demand for two things that at least apparently exclude each other, a demand, as we say, to eat your cake and have it too. Even if the children's prayer means only a demand for both of two offered alternatives, ${ }^{19}$ it still implies an insistence on both when it seems that we are required to choose one or the other. If the conclusion were merely that some beings are immovable and others are moving, there would be no paradox or apparent contradiction, no seemingly exclusive choice. Thus we are told that the philosopher, like a child demanding to "have it both ways," must say, not, as the text is often translated,

18 Surprisingly, neither Vogel (1986) nor Gerson (2006), in arguing against Cornford, Ross, et al., comments on this outrageous tampering with the text. Duerlinger (2009) 112 translates the text as it stands: "It follows then ... that if beings are not in motion, nowhere is mind present in anything or concerned with anything."

19 A. A. Milne, Winnie the Pooh, ch. 2: "[W] hen Rabbit said, 'Honey or condensed milk with your bread?' [Pooh] was so excited that he said, 'Both,' and then, so as not to seem greedy, he added, 'but don't bother about the bread, please." 
that being is both the things that are immovable and the things that are in motion, but rather that it is "as many things as are immovable and in motion, both together:" the pronoun ö $\sigma \alpha$ is not repeated, thus again suggesting that it is the same things that must be both immovable (in some sense) and moving (in some sense). This accords with the requirement to reject the claim that being is in motion "in every way [ $\pi \alpha v \tau \alpha \chi \hat{n}]$ " $(249 \mathrm{~d} 2)$. The conclusion, therefore, is not that being consists both of things that are immovable and of things that are moving, but that being consists of things that are both immovable and moving. ${ }^{20}$

How then is this seeming contradiction to be resolved? Let us note that the only "motion" that is actually demanded by the argument and attributed to being is the intellectual activity of knowing and being known, a kind of "motion," in the sense of doing and undergoing, that need not involve change in the sense of alteration over time. Being is thus both moving in the former sense and immovable in the latter sense. ${ }^{21}$ Aristotle later coins the term

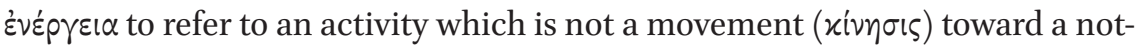
yet-achieved end, and, significantly, takes seeing and knowing as his prime examples of such activities (Metaphysics $\Theta .6$, 1048b18-35). Plato's terminology is different in that he uses the word xivnoıs to cover both motion in the sense of change and the changeless activity of intellectual apprehension, but the argument makes it clear that what he means by the "motion" and "life" of

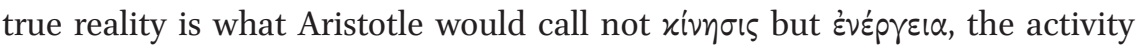
of intellection. ${ }^{22}$ Indeed, in the many passages throughout the dialogues in which Plato insists on the changelessness of intelligible being (Phaedo $78 \mathrm{~d} 1-7$, 79d2, 8ob1-2; Phaedrus 247d7-e2; Symposium 211a1-b5; Republic 479a1-3, e7-8, 484b4, 585c1-2; Parmenides 135c1; Timaeus 27d6-28a2, 29a7, 52a1-3) he never, with one exception, refers to it as "immovable." Timaeus 38 a 3 is the exception

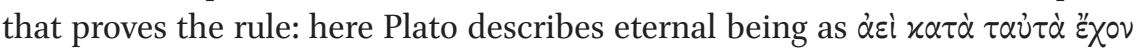
$\dot{\alpha} \varkappa\llcorner\eta \dot{\eta} \tau \omega$. But the context here is the distinction between eternity and time, so

20 Cf. the less literal but still accurate translation in Duerlinger (2009) 113: "But like children who request [both when offered a choice of two things], he must say that being and all things are both [at rest and in motion]" (brackets in original). Contrast Ross (1951) 110: "And when [Plato] says that to the question whether reality is changeable or unchangeable we must answer 'it is both', he does not mean that the same reality in some mysterious way manages to be both, but that both unchanging Ideas and changing minds are perfectly real." This, quite simply (as Ross here admits), is not what the text says. Crombie (1962) 419-20, recognizes that it is the same things that are both "changeless" and "changeable," in different ways.

22 On this terminological difference between Plato and Aristotle see Gerson (2006) 297-8 and Gerson (2004) 41 n. 6o, 217. 
that in this particular case xivnбıs unmistakably refers specifically to temporal change rather than to activity in general. In the Laws, Plato expressly discusses

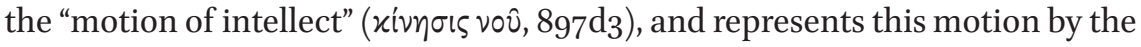
image of a sphere rotating in a fixed location. This image perfectly captures the non-contradictory coinciding of motion and rest: the entire sphere is both completely in motion and completely immobile, in different respects. ${ }^{23}$ The "motion of intellect," then, is in no way incompatible with the changelessness of intelligible being. The children's prayer is granted.

If the argument in the Sophist were the only place in the corpus where Plato even seems to attribute intellect, life, and motion to intelligible being, this interpretation, despite its close adherence to the exact wording of the text, would perhaps remain speculative. ${ }^{24}$ What renders it truly compelling is that this passage is not isolated, and does not represent a change in Plato's thought, ${ }^{25}$ but rather agrees with the relation between thought and being that we find throughout the dialogues: in the myth of recollection, in the gastronomic and conjugal metaphors for knowledge, in the relation of craftsman and paradigm, in the "intelligible living thing" of the Timaeus, and in the "motion of intellect" in the Laws. ${ }^{26}$ On the contrary, it is the caricature of the forms as lifeless objects extrinsic to the thought that knows them that has no real basis anywhere in the dialogues. The recognition that the forms are inseparably united with living intelligence not only in the Sophist, or even in the Sophist along with other supposedly "late" dialogues such as the Timaeus and the Laws, but also in the Meno, Phaedo, Phaedrus, Symposium, and Republic, lends strong support to the unitarian as opposed to the developmental reading of Plato. ${ }^{27}$

23 Gerson (2006) 298 refers to this passage in the Laws but does not remark on the image of the rotating sphere, which strongly supports his interpretation.

24 Thus, e.g., Cornford (1935) 245, argues that since "[t]he Forms are never represented as living and thinking beings," therefore this cannot be Plato's meaning here. In addition to being circular, this disregards the references in the Timaeus to "the intelligible living thing."

25 Thus Crombie (1962) 419, remarks, "There is nothing in this conclusion which reads like a recantation of anything that Plato has ever written," and again, 420, "[T]here is no reason to say that [Plato] is here repenting of the belief in unchanging forms in the only sense of 'unchanging' to which he had ever intended to commit himself."

26 On the identity of "the complete living thing" ( $\left.\pi \alpha \nu \tau \varepsilon \lambda \dot{\varepsilon} \zeta \zeta \hat{\omega}_{\mathrm{c}} \mathrm{\nu}\right)$ of the Timaeus with "that which completely is" ( $\tau \dot{0} \pi \alpha \nu \tau \varepsilon \lambda \hat{\omega} \varsigma$ oै $v$ ) of the Sophist, see Ferrari (2011).

27 Here we must differ with Vogel (1986), who finds the Plotinian doctrine in the Sophist and the Timaeus but remarks (194) that in the Phaedo, Symposium, Republic, and Phaedrus, "not a trace" of it can be found. Gerson is less explicit on this point, saying (2006) 291 n. 2, "I refrain from exploration of the developmentalist vs. unitarian conceptions of Plato's 
The conjugal unity of intellectual activity and intelligible being is Plato's uniform and consistent understanding of the relation between intellect and the forms. This reading of Plato thus takes down, at one stroke, three main pillars of modern Plato interpretation: the lifelessness of the forms, the "ocular" model of knowledge, and, at least in this important instance, the chronological development of Plato's thought.

Plato concludes the Timaeus with these words: "Having received and been filled with mortal and immortal living things, thus this cosmos, a visible living thing containing visible ones, image of the intelligible, a sensible god, greatest, best, most beautiful, and most perfect, has come to be, this which is the one only-begotten universe" (92c5-9). The expression "image of the intelligible" is provocatively ambiguous. Does it mean "of that which is intelligible, the intelligible in general"? Or "of the intelligible living thing," implied by antithesis with "visible living thing"? Or "of the intelligible god," implied by antithesis with "sensible god"? The ambiguity is no doubt deliberate, and there is no need to choose among these alternatives. The intelligible in general, intelligible being as a whole, is itself the intelligible living thing, as the content of intellect which is the intelligible god. This, intellect and the intelligible in their togetherness, is the living, divine reality of which the sensible world is an image.

\section{$4 \quad$ Aristotle and Plotinus}

Aristotle's understanding of the unity of intellect and the intelligible is thus not opposed to but in continuity with Plato's thought. ${ }^{28}$ In apprehending the intelligible, intellect has it as its content and so is the intelligible. "The intellect is in a way potentially the intelligible, but in actuality nothing before it thinks ... For in the case of things without matter, the thinking and that which is thought are

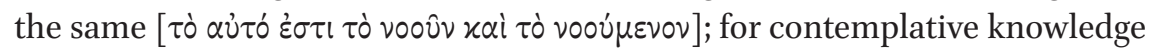

philosophy," but implies in the same note both that he accepts the assumption that the Phaedo is earlier than the Sophist and that the doctrine of the latter is not to be found in the former.

28 Owens (1978) 458, contrasts Plato and Aristotle thus: "[T]he Platonic forms are potential. They are knowables. The Aristotelian separate forms are knowings. If the terms 'intelligibles' and 'intelligences' may be used for the moment to translate these notions, the Platonic forms are merely intelligibles; the Aristotelian forms are intelligences... While the Platonic form is something as it were flat and essentially a knowable, the Aristotelian is vital and in comparison three-dimensioned..." (italics in original). Evidently Owens altogether disregards the passage in the Sophist which derides precisely this view of Plato's forms and expressly attributes activity, life, and intelligence to the intelligible. 
and that which is known in this way are the same" (On the Soul Г.4, 429b3o430a5). The human intellect is only "potentially the intelligible," and becomes the intelligible, becomes what it knows, in being actualized. The unmoved mover, on the other hand, as pure actuality, is always already both intellect and the intelligible. "Thought thinks itself by participation in the intelligible; for it becomes intelligible in touching and thinking, so that intellect and the intelligible are the same; for intellect is what is receptive of the intelligible, that is,

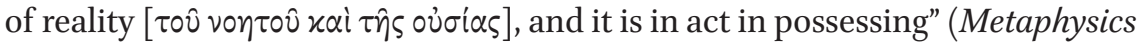
$\Lambda .7,1072 \mathrm{~b} 20-23)$. Here Aristotle adopts both Plato's metaphor of "touching" for

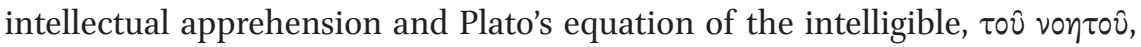

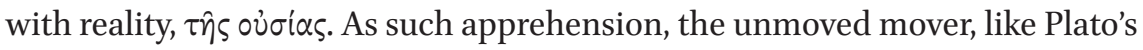
demiurge, is one with purely intelligible reality: "In some cases the knowledge is the thing... Since, then, that which is thought and the intellect [ $\tau 0 \hat{v}$

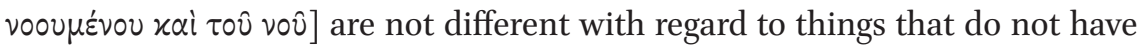

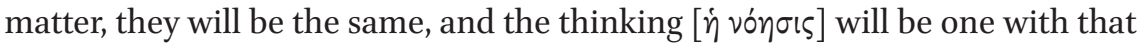

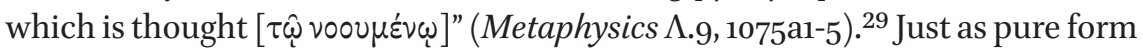
or actuality, Aristotle's god, like Plato's demiurge, is both act-of-thinking and content of thought, and as such, while changeless, is not inert or lifeless but, on the contrary, is life itself: "For the activity of intellect is life, and he is that activity" (Metaphysics $\Lambda .7,1072 \mathrm{~b} 27$ ).

It is in just this sense that the unmoved mover is "thought thinking itself" or "the thinking of thinking" (Metaphysics $\Lambda .9,1074 b 34-35$ ). This should not be taken to mean that divine thinking is "empty," devoid of content. ${ }^{30}$ On the contrary, Aristotle specifically insists that it must have content: "If it thinks nothing, what would be its dignity?" (Metaphysics $\Lambda .9,1074 \mathrm{~b} 18$ ). His point in insisting that the unmoved mover thinks only himself is not that he thinks nothing, but that what he thinks is not extrinsic to himself. ${ }^{31}$ As Aristotle observes, the notion that if the divine thinking thinks only itself then it is empty erroneously applies the model of sense-perception to thinking, presupposing that what is thought must be extrinsic to the thinking just as what is sensed is extrinsic to the sensing: "But it appears that knowledge and sensation

29 In Aristotle as in Plato, it is inappropriate to translate vooú $\mu \varepsilon v o v$ as "object of thought." Indeed, if 'object' is taken to mean "that which stands over against," then it is almost the exact opposite of what Aristotle means, since his fundamental point is that that which is thought or known is not over against but is rather one with the thinking or knowing.

30 Cf. Owens (1978) 458-59 n. 23: "Matter as such has no intelligible content whatsoever. The whole 'content' is the form. It is therefore meaningless to ask what the Aristotelian 'selfthinking' is about, on the ground that it is deprived of sensible reference." 
and opinion and understanding are always of another, and of itself only as a byproduct... For it is not the same to be an act-of-thinking and to be that which is thought" (Metaphysics 4.9 , 1074b36-75ar) This is not Aristotle's own position, but an objection to which he will reply: "Rather, in some cases the knowledge is the thing." In what cases? Again, "Since, then, that which is thought and the

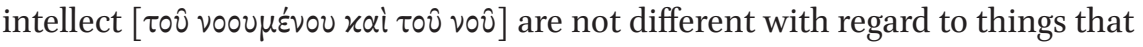
do not have matter, they will be the same, and the thinking [ $\dot{\eta}$ vónoıs] will be

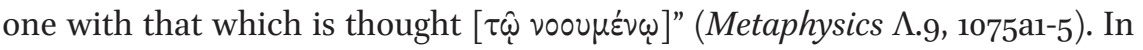
the case of sensible things, matter is the difference, the element of externality, between cognition and that which is cognized. But where the latter is nothing but form, there is no such externality. To say that the divine thinking thinks itself, therefore, is to say that it is the thinking, not of nothing, but of intelligible reality, form without matter. Since the unmoved mover is knowledge itself, he is one with the formal, intelligible content of the world without matter, and this is what he knows in knowing himself. ${ }^{32}$ As in Plato, intelligible reality is not apart from but is the content of the activity of intellectual apprehension, which is what the unmoved mover is.

In arguing for the unity of intellect and the intelligible, therefore, Plotinus is not innovating but is following the thought of both Plato and Aristotle. To be sure, unlike Aristotle, Plotinus argues at length that this unity cannot be a simple or absolute identity. Within the "one nature" (v.5.3.1) which is at once intellect and being, Plotinus finds it necessary to distinguish, although never to separate, intellect as act and being as content. This follows from Plotinus' recognition of the intentionality of thinking: "Every intellection is from something and of something" (VI.7.40.6). Hence there must be an otherness as well as a togetherness between intellect and that which it thinks, even if the latter is its own content and in that sense itself: "Its intellection about itself must

32 Cf. Kahn (1985) 326: "Essences considered apart from matter are ungenerated and imperishable... Taken as immaterial and delineated by their universal definition, such essences are fully intelligible (noèta) ... They also, on my reading of $\Lambda$, provide the content for the noetic act of the divine Intellect." Kahn adds, 327 n. 24, "The more completely a human being engages in noetic contemplation, the more fully he grasps the formal structure of the cosmos. If the divine represents the goal to which human thought at its best aspires, surely the divine must grasp the whole of this structure rather than none of it!... Reflexion must be reflexion on something which is not itself reflexion... Hence nous is determined or defined by the essences which are its objects... The counter-objection, that the divine mind would be less perfect if it knew anything other than itself, is spurious, just because in actual noēsis the knowing subject is identical with its object. Drastically put, the Prime Mover is simply the formal-noetic structure of the cosmos as conscious of itself" (italics in original). 
be of something different, if it is to be able to think itself as anything at all" (vI.7.39.12-13). Without this otherness, there would be no intentionality, no apprehending of anything, and hence neither intellect nor the intelligible. "But if intellect, intellection, intelligible are the same, by becoming altogether one $\left[\pi \alpha^{2} v \tau \eta \bar{\varepsilon} \nu\right]$ they will make themselves disappear in themselves" (VI.7.41.12-13). Apprehension is a single occurrence which, necessarily, can be analyzed into the apprehending and the apprehended, the knowing and the known. It takes two to "be together." Intellect as act-of-thinking and being as that-which-isthought must coincide, but 'intellect' and 'being' do not have the same meaning. The first signifies act and the second content, two inseparable moments (not parts) of a single reality. "That which thinks, then, when it thinks, must be in two, either one outside the other or both in the same; and by necessity thinking is always in otherness and in sameness, and the things that are properly thought are both the same and different in relation to intellect" (v.3.10.23-26). Hence, "in that it thinks it is two and in that it thinks itself, one" (v.6.1.23). For this reason, Plotinus argues, against Aristotle, that this "one nature" cannot be the first principle. But this difference between Plotinus and Aristotle not only occurs within, but depends on, their underlying continuity with regard to the necessary togetherness of intellect and the intelligible. It is from this startingpoint, which Plotinus shares with both Plato and Aristotle, that he argues that thinking and being must be distinct in order to be united, and hence cannot be unqualifiedly first.

In v.9, after giving arguments for the unity of intellect and being, Plotinus cites as testimonies to this doctrine not only Parmenides, "Thinking and being are the same" (DK в 3), but also Aristotle, "The knowledge of things without matter is the same as the thing" (On the Soul $\Gamma .4,430 a 3$ ) and Plato, "the recollections" (v.9.5.29-32). This shows, incidentally, that Plotinus understands Plato's myth of recollection as we have interpreted it here, as an expression of the internality of the intelligibles to the act of intellection. This catalogue of testimonies is no mere collection of proof-texts having no real bearing on the issue at hand, but, on the contrary, reveals Plotinus' profound understanding of the philosophical tradition to which his doctrine belongs.

The Neoplatonic principle that intelligible being is one with living intelligence is thus fully continuous with both Plato's and Aristotle's understandings of the relation between intellect and the intelligible and of the nature of purely intelligible, divine reality. This recognition contributes to a salutary "paradigm shift" that is currently taking place in the study of ancient philosophy. For too long, the standard, "textbook" account has set Aristotle in opposition to Plato, and dismissed Neoplatonism as a marginal or even aberrant development. Instead, with regard to this doctrine as well as many others, we are now com- 
ing to see a continuous line of thought leading from Plato through Aristotle to Plotinus and the Neoplatonists. This change in perspective not only offers a more authentic understanding of Aristotle in his relation to Plato, but also enables us to see Neoplatonism not as a bizarre offshoot but as the main trunk of the classical tradition, and indeed as its fullest flowering.

\section{Bibliography}

Bluck, Richard S. 1975. Plato's Sophist. Manchester: University Press.

Brown, Lesley. 1998. "Innovation and Continuity: The Battle of Gods and Giants, Sophist 245-249." In Method in Ancient Philosophy, ed. Jyl Gentzler. Oxford: Oxford University Press.

Cornford, F. M. 1935. Plato's Theory of Knowledge. London: Routledge and Kegan Paul.

Crombie, I. M. 1962. An Examination of Plato's Doctrines, vol. 2. London: Routledge and Kegan Paul, 1962.

Desjardins, Rosemary. 2004. Plato and the Good: Illuminating the Darkling Vision. Leiden and Boston: Brill.

Dorter, Kenneth. 1972. "Equality, Recollection, and Purification." Phronesis 17, 198-218.

Duerlinger, James, tr. 2009. A Translation of Plato's Sophist with an Introductory Commentary. New York: Peter Lang.

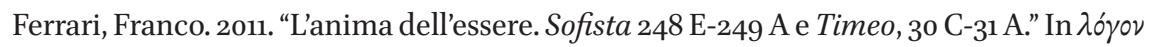

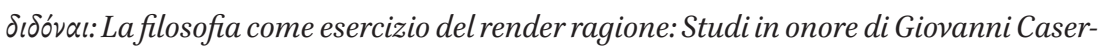
tano, ed. Lidia Palumbo. Naples: Loffredo Editore.

Gerson, Lloyd P. 2004. Aristotle and Other Platonists. Ithaca: Cornell University Press. 2006. "The 'Holy Solemnity of Forms and the Platonic Interpretation of Sophist." Ancient Philosophy 26, 291-304.

Griswold, Charles L. 2002. "Comments on Kahn." In New Perspectives on Plato, Modern and Ancient, ed. Julia Annas and Christopher Rowe. Washington: Center for Hellenic Studies.

Hadot, Pierre. 196o. "Etre, vie, pensée chez Plotin et avant Plotin." In Entretiens Hardt v: Les sources de Plotin. Geneva: Fondation Hardt.

Heidegger, Martin. 1996. "Platons Lehre von der Wahrheit." In Wegmarken, 3rd ed. Frankfurt am Main: Vittorio Klostermann.

Howland, Jacob. 1991. "Re-Reading Plato: The Problem of Platonic Chronology." Phoenix 45, 189-214.

Kahn, Charles. 1985. "On the Intended Interpretation of Aristotle's Metaphysics." In Aristoteles Werk und Wirkung, vol. 1, Aristoteles und seine Schule, ed. Jürgen Wiesner. Berlin: Walter de Gruyter.

Leigh, Fiona. 2010. "Being and Power in Plato's Sophist." Apeiron 43, 63-85. 
Owens, Joseph. 1978. The Doctrine of Being in the Aristotelian Metaphysics, 3rd ed., rev. Toronto: Pontifical Institute of Mediaeval Studies.

Peperzak, Adriaan. 1997. Platonic Transformations. London and New York: Rowman and Littlefield.

Pépin, Jean. 1965. "Éléments pour une histoire de la relation entre l'intelligence et l'intelligible chez Platon et dans le néoplatonisme," Revue philosophique 146, 39-64. Perl, Eric D. 1998. "The Demiurge and the Forms: A Return to the Ancient Reading of the Timaeus." Ancient Philosophy 18, 81-92. 2014. Thinking Being: Introduction to Metaphysics in the Classical Tradition. Leiden and Boston: Brill.

Rorty, Richard. 1979. Philosophy and the Mirror of Nature. Princeton: Princeton University Press.

Ross, Sir David. 1951. Plato's Theory of Ideas. Oxford: Oxford University Press.

Sayre, Kenneth M. 2005. Plato's Late Ontology: A Riddle Resolved, new ed. N.p.: Parmenides Publishing.

Vogel, C. J. de. 1986. Philosophia I: Studies in Greek Philosophy. Assen: Van Gorcum.

White, Nicholas P., tr. 1997. Sophist. In Plato: Complete Works, ed. John Cooper. Indianapolis: Hackett. 